\title{
Lamb growth simulation through Pampa Corte model adapted to sheep
}

\author{
Simulação do crescimento de cordeiros através do modelo Pampa Corte adaptado para ovinos
}

\author{
Vicente Celestino Pires Silveira' Javier Álvarez-Rodríguez ${ }^{\text {II }}$ Margalida JoyI Albina Sanz ${ }^{\text {II }}$ \\ Alberto Bernués ${ }^{I I}$
}

\begin{abstract}
The Pampa-Corte model developed to simulate growth of beef cattle was adapted to simulate lamb growth. This paper has the objective to describe the main modifications and the fitness of model in the simulations of lamb growth. To validate the model two datasets from Centro de Investigación y Tecnología Agroalimentaria de Aragón (Zaragoza, Spain) were used. The first one used data from 29 male and 10 female lambs of Rasa Aragonesa breed born in spring of years 2005, 2006 and 2008. The second data came from 32 male lambs of Churra Tensina breed born in spring of years 2004 and 2007. The model showed good fit between observed and simulated data in intensive finishing lamb systems, although small deviations were observed after slaughtering the first animals that reached the commercial live-weight $(L W)$ of $22 \mathrm{~kg}$.
\end{abstract}

Key words: animal model, intensive finishing system, sheep model.

\section{RESUMO}

O modelo Pampa Corte, que foi desenvolvido com a finalidade de simular o crescimento corporal de bovinos de corte, foi adaptado para a simulação do crescimento de ovinos. Este artigo tem como objetivo descrever as principais modificações e o desempenho do modelo na simulação do crescimento de cordeiros. Para a avaliação do modelo, foram utilizados dois conjuntos de dados de dois experimentos do Centro de Investigación y Tecnología Agroalimentaria de Aragón, Zaragoza, Espanha. O primeiro conjunto contém dados de 29 cordeiros e 10 cordeiras da raça Rasa Aragonesa, nascidos na primavera dos anos 2005, 2006 e 2008. O segundo conjunto com dados experimentais de 32 cordeiros da raça Churra Tensina, nascidos na primavera de 2004 e 2007. Os resultados simulados pelo modelo, quando comparados com os dados experimentais, demonstraram um ótimo desempenho do modelo, principalmente até o início do abate dos primeiros animais que alcançavam o peso meta experimental de $22 \mathrm{~kg}$. O modelo Pampa Corte adaptado para a simulação de crescimento de ovinos demonstrou alta precisão na simulação em sistemas intensivos de engorda de cordeiros.

Palavras-chave: modelo animal, modelo ovino, sistema terminação intensivo.

\section{INTRODUCTION}

Sheep simulation models have been reviewed by BERNUÉS et al. (1995), at different levels of aggregation: animal, herd, farm and regional planning resources. However, models that represent individual animal performance are still scarce in literature (FREER et al., 1997; CANNAS et al., 2004; CASTELLARO et al., 2006). The Pampa Corte model was developed in order to simulate beef cattle live-weight gain in a dynamic and mechanistic way (SILVEIRA, 2002; TREVISAN et al., 2009; SILVEIRA et al., 2011).

Lamb production in the Mediterranean region, especially in Spain, combines a wide diversity of grazing-based systems to manage the flocks of adult ewes with highly intensive finishing systems based on early weaning (45-60 days) and subsequent feeding with concentrate in order to obtain light carcasses called “Ternasco" or "Recental” of 18 to 26kg live-weight (LW), as described by JOY et al. (2008). This finishing system

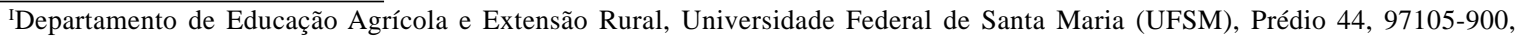
Santa Maria, RS, Brasil. E-mail: vicentesilveira@smail.ufsm.br. Autor para correspondência.

${ }^{\mathrm{II} C e n t r o ~ d e ~ I n v e s t i g a c i o ́ n ~ y ~ T e c n o l o g i ́ a ~ A g r o a l i m e n t a r i a ~ d e ~ A r a g o ́ n ~(C I T A ~ d e ~ A r a g o ́ n), ~ Z a r a g o z a, ~ S p a i n . ~}$ 
is highly dependent on the prices of grains and byproducts, thus simulation models that generate alternative scenarios might be useful in farmers' decision-making.

This article aims to describe the Pampa Corte model modifications for lamb production and verify its predictive behavior when simulating live-weight changes of Rasa Aragonesa and Churra Tensina lambs in conventional intensive finishing systems in Spain.

\section{METHODOLOGY}

The sheep model uses the same methodological framework of the original Pampa Corte model (SILVEIRA, 2002). Individual animal performance was generated from two sub-models: the first sub-model simulates the consumption and digestion of food, and has as main outputs estimates of animal intake and daily energy and metabolic protein production; the second sub-model considers these productions to simulate animal growth based on AFRC (1993) and CSIRO (2007) equations. The initial variables and parameters required by the model can be found in SILVEIRA(2002).

To validate the model data derived from previous works at the Centro de Investigación y Tecnología Agroalimentaria de Aragón research station (Zaragoza, Spain) were used. The first dataset contained data from 29 male and 10 female lambs of Rasa Aragonesa born in the springs of 2005, 2006 and 2008. All lambs were weighed weekly and slaughtered when they reached the target weight of $22 \mathrm{~kg} \mathrm{LW}$. The lambs were weaned between 45 and 55 days of age. After weaning, animals were housed and received concentrate (commercial feed) and barley straw ad libitum. Feedstuffs were analyzed for neutral detergent fibre (NDF) (VAN SOEST, 1964), crude protein (CP) (AOAC, 1984) and in vitro digestibility (IVD) (TILLEY \& TERRY, 1963) (Table 1 ). The reported values of protein degradation products were obtained from AFRC (1993). For protein and NDF degradation, a passage rate of $5 \%$ per hour was considered. The values of diet NDF degradation obtained through the technique of gas production (THEODOROU

Table 1 - Feedstuffs chemical composition (\% of DM).

\begin{tabular}{lcc}
\hline & Concentrate & Barley straw \\
\hline Neutral detergent fibre (NDF) & 16.95 & 63.59 \\
Crude protein (CP) & 18.64 & 4.86 \\
In vitro digestibility (IVD) & 83.00 & 48.60 \\
\hline
\end{tabular}

et al., 1994) were 0.080 per hour for concentrate and 0.026 per hour for barley straw.

The second database contained experimental data from 32 Churra Tensina lambs, born in the springs of 2004 and 2007, belonging to the herd from the La Garcipollera experimental station of CITA de Aragon. All lambs were also weighed weekly and slaughtered as they reached the target weight of $22 \mathrm{~kg}$ (ALVAREZ-RODRIGUEZ et al., 2008). The lambs were weaned between 45 and 55 days of age and afterwards kept in stalls and fed with commercial feed and barley straw ad libitum. Feed was analyzed for neutral detergent fibre (NDF), crude protein (CP) and the in vitro digestibility (IVD) determined considering a passage rate of $5 \%$ per hour. Lamb managing and feedstuff analysis were the same explained above.

\section{RESULTS AND DISCUSSION}

One goal of developing simulation models is to identify knowledge gaps. The sub-model that simulates the digestion of food consumption was designed for extensive ruminant production systems. Therefore, it assumes that cell content is fully degradable, although valid for forage is not completely applicable in the case of commercial concentrates due to the high cellular content. To correct for this, the degradation was determined in vivo during 48h for 6 samples of commercial concentrate, which confirmed average cellular content degradability of $95 \%$. Another fact to consider is that the intake sub-model only considers physical constraints of consumption through rumen capacity (ILLIUS \& GORDON, 1991; SILVEIRA, 2002), whilst the consumption of commercial feed may have metabolic restrictions (VAN SOEST, 1994). To simulate this effect, an equation for reducing consumption (RC) was created based on AFRC (1993): $\mathrm{RC}=24,567 \mathrm{xqm}^{2}-34,694 \mathrm{xqm}+12,918$. Thus, when the dietary energy level is greater than $11 \mathrm{MJ} \mathrm{kg}^{-1} \mathrm{DM}$ and the metabolisability of gross energy of diet at maintenance $[\mathrm{ME}] /[\mathrm{GE}]$ (qm) for equal at 0.59 , the calculated equation has a direct effect on rumen capacity, and therefore restricts consumption. The second modifications needs for the model were the change of all equations to simulate animal growth from beef cattle to sheep according AFRC (1993).

Figure 1 shows the performance of the model on estimating Rasa Aragonesa lamb live-weight gain after weaning. In the case of females, the simulated live-weight was higher than the observed. An AFRC (1993) report, especially for females, the inclusion of an adjustment factor in energy is requested to improve 


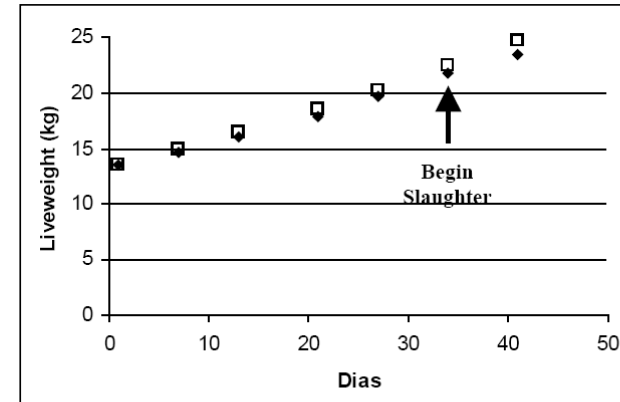

- Actual 2005 口 Simulate 2005

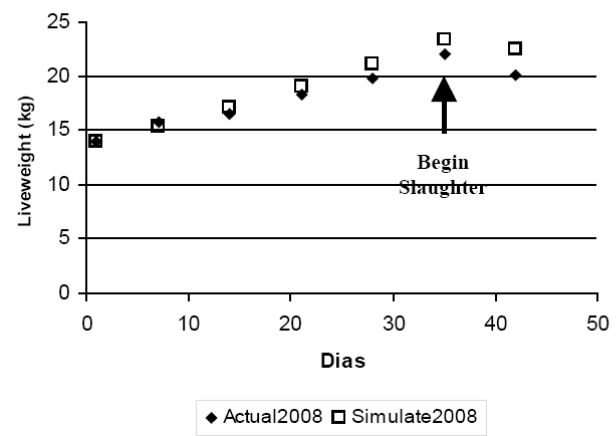

Figure 1 - Actual and simulate growth of Rasa Aragonesa lambs from weaning to slaughtering.

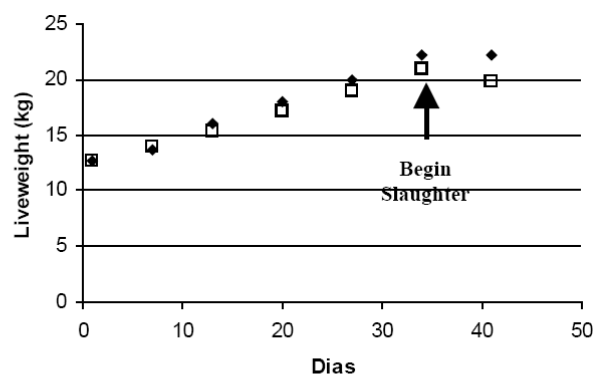

- Actual 2006 口 Simulate 2006

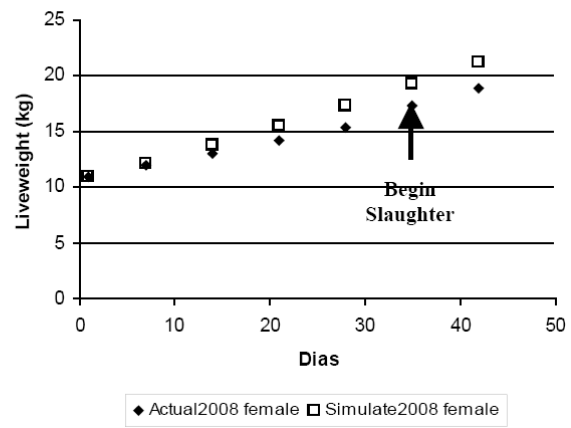

- Actual2008 female 口 Simulate2008 female weight gain estimates, similar to those used for cattle. There was a significant prediction improvement after introducing a 1.3 adjustment factor. New validations with female lambs should be carried out in order to confirm this assumption. As for male lambs, the model outputs were very close to observed data until the first animals reaching the targeted LW were slaughtered. After that moment, there was a small difference between observed and predicted final weight. In figure 2, it can be seen that when animals were separated into two groups according to slaughter time, early (first animals slaughtered) and late (all the others), there was higher dispersion of predicted values for the latter group. This is probably due to the fact that in these production systems animals with health problems, especially respiratory and digestive (paraqueratosis, acidosis), may occur. These problems interfere with live-weight gain, however, the model does not consider health factors. Therefore, the development and / or adaptation of models that can consider these factors is advisable, since only nutritional limitations and environmental stress are now taken into account.

Figure 3 shows the results simulated by the model for the second experiment, with Churra Tensina

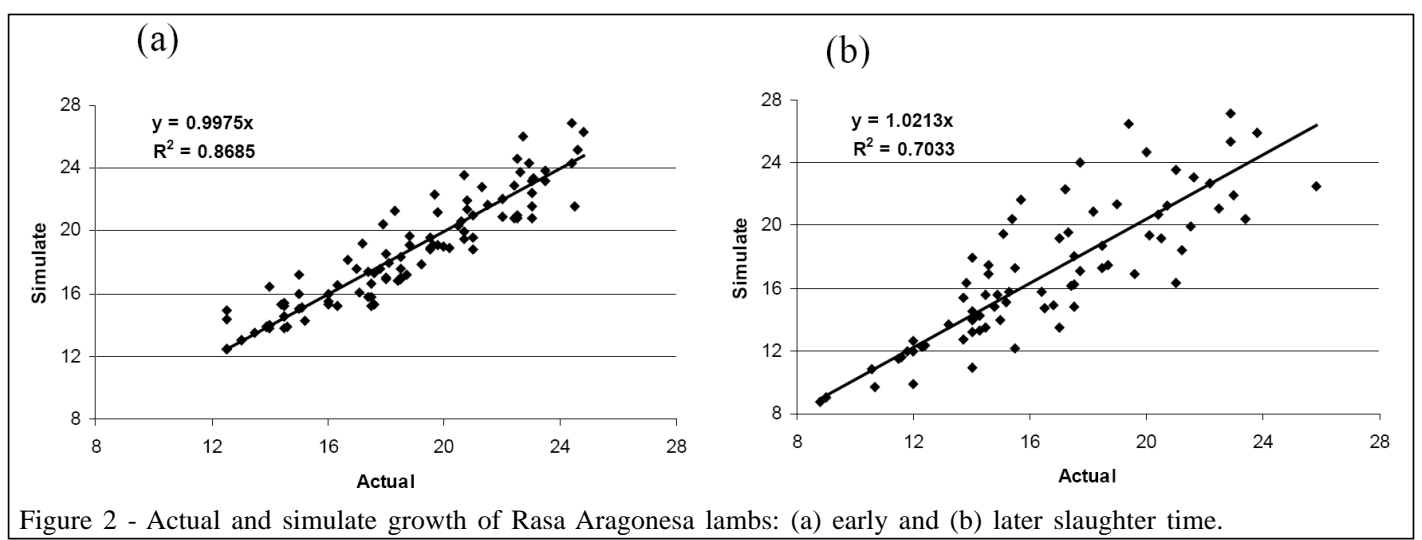

Ciência Rural, v.42, n.11, nov, 2012. 


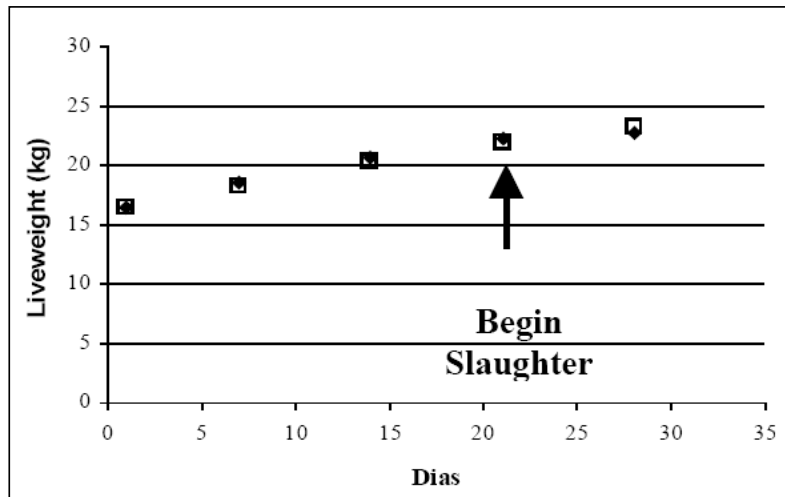

- Actual 2004 口 Simulate 2004

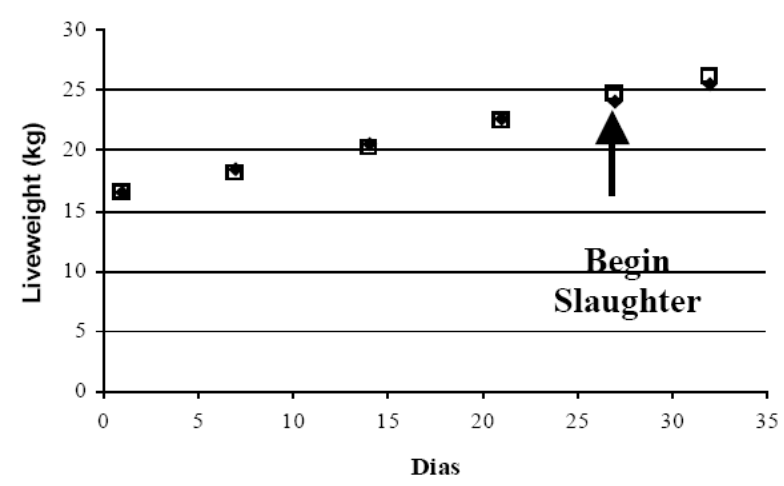

- Actual 2007 口 Simulate 2007

Figure 3 - Actual and simulate growth of Churra Tensina lambs from weaning to slaughtering, in the years 2004 and 2007.

animals. Again, once compared with observed experimental data, the model performance for the two years studied is optimal, mainly until the beginning of the slaughter of animals that achieved the targeted weight earlier (22kg LW). Similarly, when animals were separated into two lots, early and late slaughter, the best results were observed in the early slaughter group (Figure 4).

\section{CONCLUSION}

The Pampa Corte model adapted to simulate lambs growth shows high accuracy on simulating intensive fattening systems of lambs. The development and / or adaptation of models that consider health factors should be incorporated to improve the prediction for animals with slower growth.

\section{ACKNOWLEDGEMENTS}

To Universidade Federal de Santa Maria (UFSM), the Coordenação de Aperfeiçoamento de Pessoal de Nível Superior (CAPES) and Centro de Investigación y Tecnologia Agroalimentaria de Aragón (CITA), for allowing my postdoctoral internship and making this article possible. Funding coming from INIA (OVISAT-00170-RTA2006, RTA200800098, RTA2003-00031, RZP2004-00008,) and FEDER. (a)

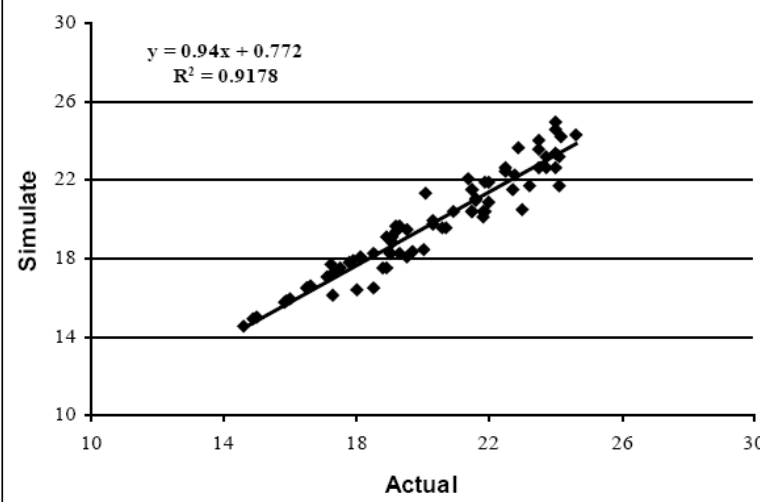

(b)

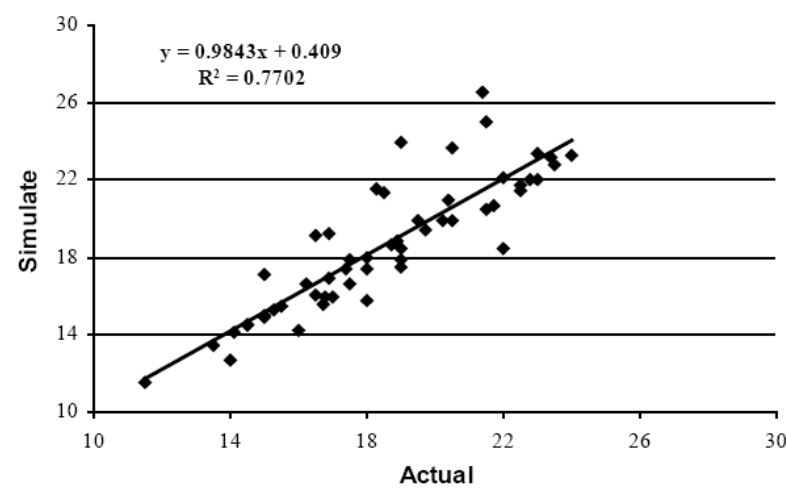

Figure 4 - Actual and simulate growth of Churra Tensina: (a) early and (b) later slaughter time. 


\section{REFERENCES}

AFRC. Energy and protein requirements of ruminants. Wallingford: CAB International, 1993. 159p.

ALVAREZ-RODRIGUEZ, J. et al. Growth analysis in light lambs raised under different management systems. Small Ruminant Research, v.79, p.188-191, 2008. Available from: <http://www.sciencedirect.com/science/article/pii/ S0921448808001727> Accessed: March. 20, 2011. doi: 10.1016/j.smallrumres.2008.08.003.

A.O.A.C. Official methods of analysis. 14.ed. New York, 1984. 1141p.

BERNUÉS, A. et al. El estudio de los sistemas ganaderos mediante simulación: una revisión de los modelos de ovino a nivel del animal individual, del rebano y de la explotación. Investigación Agraria Producción y Sanidad Animales, v.10, p.243-272, 1995.

CANNAS A. et al. A mechanistic model to predict nutrient requirements and feed biological values for sheep in each unique production situation. Journal of Animal Science, v.82, p.149169, 2004.

CASTELLARO, G. et al. Interaction of two simulation models for the evaluation of sheep production systems in the Mediterranean-type Region of Chile. Ciencia e Investigacion Agraria, v.33, p.41-49, 2006.

COMMONWEALTH SCIENTIFIC AND INDUSTRIAL RESEARCH ORGANISATION - CSIRO PUBLISHING. Nutrient requirements of domesticated ruminants. Collingwood, Autralia, 2007. 270p.

FREER, M. et al. Decision support systems for Australian grazing enterprises. II. The animal biology model for feed intake, production, and reproduction and the GrazFeed DSS. Agricultural Systems, v.54, p.77-126, 1997. Available from: <http://dx.doi.org/10.1016/j.bbr.2011.03.031>. Accessed: March. 20, 2011.

ILLIUS, A.W.; GORDON, I.J. Prediction of intake and digestion in ruminants by a model of rumen kinetics integrating animal size and plant characteristics. Journal of agricultural science, v.116, p.145-157, 1991.
JOY, M. et al. Ewe metabolic performance and lamb carcass traits in pasture and concentrate-based production systemsin Churra Tensina breed. Small Ruminant Research, v.75, p.24-35, 2008. Available from: <http://www.smallruminantresearch.com/ article/S0921-4488(07)00180-0/fulltext>. Accessed: Apr. 06, 2011. doi: 10.1016/j.smallrumres.2007.07.005.

MEHREZ, A.Z.; ORSKOV, E.R. A study of the artificial fibre bag technique for determining the digestibility of feeds in the rumen. Journal of Agricultural Science, v.88, p.645-650, 1977.

SILVEIRA, V.C.P. Pampa corte - um modelo de simulação para o crescimento e engorda de gado de corte. Ciência Rural, v.32,n.3, p.543-552, 2002. Available from: <http://www.scielo.br/ scielo.php?script=sci_arttext\&pid=S0103-84782002000300029 \&lng=es\&nrm=iso>. Accessed: Mar. 15, 2011. ISSN 0103-8478. doi: 10.1590/S0103-84782002000300029.

SILVEIRA, V.C.P. et al. Evaluation of "Pampa-corte" simulation model in different beef cattle fattening systems in Spain. Ciência Rural, v.41, n.3, p.497-500, 2011. Available from: <http:// www.scielo.br/scielo.php?script=sci_arttext\&pid=S010384782011000300022\&lng=pt\&nrm=iso>. Accessed: Apr. 06, 2011.

THEODOROU, M.K. et al. A simple gas production method using a pressure transducer to determine the fermentation kinetics of ruminant feeds. Animal Feed Science and Technology, v.48, p.185-197, 1994.

TILLEY, J.M.A.; TERRY, R.A. A two-stage technique for the in vitro digestion of forage crops. Journal of the British Grassland Society, v.18, p.104-111, 1963.

TREVISAN, N. de B. et al. Desempenho de bovinos simulado pelo modelo Pampa corte e obtido por experimentação. Ciência Rural, v.39, n.1, p.173-181, 2009. Available from: <http://www.scielo.br/ s c i e l o.ph p ? s c r i p t = s c i_art t ex t \& pi d = S 0103 84782009000100027\&lng=es\&nrm=iso>. Accessed: Mar. 05, 2011. ISSN 0103-8478. doi: 10.1590/S0103-84782009000100027.

VAN SOEST, P.J. Nutritional ecology of the ruminant. Ithaca: Cornell University, 1994. 476p.

VAN SOEST, P.J. New chemical procedures for evaluation of forages. In: Symposium on nutrition forage and pasture. Journal of animal science, v.23, p.838-845, 1964. 